\title{
Dose Not Changed
}

National Cancer Institute

\section{Source}

National Cancer Institute. Dose Not Changed. NCI Thesaurus. Code C49504.

An indication that a medication schedule was continued without modification. 